\title{
“Things begin to speak by themselves": Pierre Schaeffer's myth of the seashell and the epistemology of sound
}

-- Iain Campbell

[draft only, final version in Sound Studies, DOI: 10.1080/20551940.2020.1831803]

\begin{abstract}
This paper considers the role of myth and phenomenology in Pierre Schaeffer's research into music and sound, and argues that engagement with these themes allows us to rethink the legacy and contemporary value of Schaeffer's thought in sound studies. In light of critique of Schaeffer's project, in particular that developed by Brian Kane and Schaeffer's own apparent self-disavowal, this paper returns to Schaeffer's early remarks on the "myth of the seashell" in order to examine the conditions of this critique. While Kane argues that Schaeffer's recourse to myth, coupled with his adoption of Husserlian phenomenology, leads to a closure of his inquiry and a failure to accommodate the contingency of his position, this paper argues that Schaeffer's myth of the seashell brings into focus an open-ended, motivating phenomenological problem concerning subjectivity and objectivity that runs through his thought. Drawing on the philosophical work of Gaston Bachelard and Gilles Deleuze, this paper considers the epistemological significance of this moment in Schaeffer's thought, suggesting a "problematic" account of the myth of the seashell that puts Schaeffer into conversation with contemporary work in epistemology.
\end{abstract}

Keywords: Pierre Schaeffer, myth, phenomenology, sound objects, Gaston Bachelard

\section{Introduction}

The legacy of Pierre Schaeffer's research into sound and music from the 1940s through to the 1960 s, from his early radiophonic experiments through to the publication of his Treatise on Musical Objects, is a contested one. In sound studies, concepts of Schaeffer's such as the sound object, acousmatic listening, and reduced listening are in wide use, but his thought and these notions have also been subject to widespread critique. Schaeffer has been presented as someone not only out of step with the contemporary concerns of sound studies, but perhaps even out of step with his own time, maintaining an outmoded and limited form of phenomenological inquiry while poststructuralist thought bloomed around him. In particular, the pairing in Schaeffer's thought of the phenomenology of Edmund Husserl and a reliance on a mythic function in the form of the Pythagorean veil and the akousmatikoi has been argued to lead to an idealist closure, producing a set of concepts that exclude cultural, historical, technological, and social contingency. ${ }^{1}$ But even before this

\footnotetext{
Brian Kane's (2014) treatment of acousmatic listening provides the most thorough explication of this position, but aspects of it can also be found in Kahn (1999), Kim-Cohen (2009), Chinn (2020), and much other contemporary writing on Schaeffer. Regarding Schaeffer's own time,
} 
Schaeffer came to be his own harshest critic, in his later writings and interviews seeming to disavow his musical research project.

In this article I take a different perspective. Revisiting Schaeffer's early remarks on the "myth of the seashell", I will take this as an opportunity to reflect on the role of myth and of phenomenology in Schaeffer's thought, and will outline some of the consequences of rethinking these themes. I do not deny that a certain closure occurs by the time of his Treatise, as with the "typo-morphology" that is the most prominent formal outcome of that project. However, I will argue that the myth of the seashell not only provides a different perspective on the role of myth in Schaeffer's theory, but suggests that the specific role and function of phenomenology in Schaeffer's thought should also be reconsidered. In reevaluating this moment I will argue that a phenomenological problem that the myth of the seashell brings to light, a problem of doing justice to both subjectivity and objectivity, remains active in Schaeffer's thought, and complicates any swift critique of his phenomenological tendencies. We will see that what Schaeffer takes from phenomenology is not only a method, or theses about subjectivity, but a problem.

In an insightful recent article Lisa Chinn (2020) suggests that Schaeffer's coupling of immanent phenomenological experience and transcendent material event leads to an aporia that is troubling not only for Schaeffer's thought but for the adoption of his concepts within sound studies. Here, on the contrary, I will argue that what Chinn identifies as an aporia, and Schaeffer himself understood as a source of failure, rather marks the identification of a legitimate and persisting problem concerning subjectivity and objectivity that remains relevant in sound studies today. ${ }^{2}$ In so doing I will suggest a distinction between what I call the esoteric and exoteric effects of myth, the former a logic of uncovering or rediscovering associated with the Pythagorean veil, the latter a logic of creation or fabulation associated with the seashell. In short, the myth of the seashell thematises objectivity, and thus subjectivity, differently than the myth of the veil is purported to. With this, I will argue, comes an opportunity to rethink the legacy of Schaeffer in sound studies, and to challenge

Patrick Valiquet richly details the intellectual and philosophical context of Schaeffer's work on the Treatise on Musical Objects, and quotes Michel Chion in noting Schaeffer's lack of concern with "psychoanalysis, Marxism, [or] other current disciplines", with Schaeffer thus "not count[ing] on fashion to carry" the Treatise (2017, 260). In situating Schaeffer's thought in terms of the simultaneous emergence of poststructuralism, James Steintrager and Rey Chow also tacitly point to Schaeffer's inattention to this work (2019, 8-11). Being out of step with the day's trends would not be an issue in itself, but, as Steintrager and Chow note, departing from phenomenology was a major motivating force behind poststructuralist thought (2019, 9). A set of critiques of phenomenology on the basis of naiveté or essentialism were prominent at this time, and these continue to be heard in recent interpretations of Schaeffer. Yet history has shown phenomenology to be more resistant to critique than this 1960s moment suggested (see Alloa, Chouraqui, and Kaushik 2019, 2-5), and reevaluating Schaeffer's engagement with phenomenology thus remains a potentially fruitful path.

${ }^{2}$ For example, Kane's influential critique of the "ontological turn" in sound studies could be viewed as concerning a decoupling of subjective and objective (2015). 
the purported closures of his thought with what could be termed a problematic approach to sound. Through this approach the phenomenological inquiry into sound would remain mobile, and the question of "knowing" sound would shift towards one of occupying and explicating an encounter with sound. ${ }^{3}$

\section{The myth of the seashell}

In his 1944 article "Notes sur l'expression radiophonique”, Pierre Schaeffer, then primarily a radio broadcaster, reflected on what he later called "the myth of the seashell". ${ }^{4}$ Recounting a childhood experience, Schaeffer speaks of bringing to his ear a seashell and finding there, as many have, the sound of the ocean (1970a, 90). When a little older he is disabused of this discovery, learning of the scientific perspective which says that the sound encountered is blood circulating in the ear. But writing here Schaeffer returns to credulity of his youth, the "childlike instinct" that immediately finds an analogy between "the ear, the shell, the ocean, or, if you like, man, the instrument, the universe”. Against a scientific perspective that would posit an irreconcilable split between humanity and the universe, the remarkable object that is the seashell reveals a profound, intrinsic resonance between the two, promising a renewed coupling of the subjective and objective.

John Dack has argued that the radiophonic art that Schaeffer was concerned with in this period paved the way for his musical research that followed (1994, 3). Can the foundational role that the childhood tale of the seashell takes on in "Notes sur l'expression radiophonique" thus be followed into Schaeffer's musical research, the musical research that passed through the invention of musique concrète and the "discovery" of the sound object and reduced listening, culminating with 1966's expansive Treatise on Musical Objects? Here I aim to trace the path suggested by this proposal.

Schaeffer is far from alone in finding a mythic character in seashells. In the anthropologist Stefan Helmreich's sketch of the cultural image of the seashell, he remarks that we find a history

that has, first, shells singing, speaking, sighing, and echoing distant oceanic and communal pasts, and next, shells reflecting back the personal and present moment, and, then, as we approach today, delivering sounds imagined deep inside, rather than outside, human bodies. (Helmreich 2012-13)

${ }^{3}$ In this respect the thoughts I outline here may be read alongside the "acoulogy" that Michel Chion (2016) in particular has developed following Schaeffer's coinage. Chion's approach diverges from Schaeffer's universalism towards a broadly deconstructive approach, and considering "the myth of the seashell" promises to clarify why Chion nevertheless continues to find Schaeffer to be a rich resource for thinking about sound.

4 "Notes sur l'expression radiophonique" was written in the same year as Schaeffer's "radiophonic opera" La Coquille à planètes, and in his 1970 collection Machines à communiquer is placed under the heading "Le mythe de la coquille" (Schaeffer 1970a, 89). See Dack (1994) and Nadrigny (2013). 
Helmreich notes the particular oddness of this final image, associated with the notion of the seashell revealing to the listener the circulation of blood in their ears. This not only, contrary to Schaeffer's remarks, contradicts the now accepted scientific explanation, which tells us that the sound heard is the shell resonating with the vibrating air of the environment around us, but the scientific explanation even seems to predate this popular idea. A mythic function of the seashell has here supplanted science. But that a personal image supplants the scientific image may be attributable to more than mere ignorance. Even Immanuel Kant considers seashells when reflecting on the puzzle of the "beautiful" and the apparent purposiveness we find in nature (2000, 5:297), ${ }^{5}$ and Helmreich's cultural history of seashells reveals that they have often come to symbolise or evoke fundamental aspects of how communities engage with and understand the world around them, having a shifting, ambiguous relationship with what it means to know something.

Yet Schaeffer would later introduce "Notes sur l'expression radiophonique" by stating that "times have changed", saying that he "would no longer write these romantic lines in the shadow of [Paul] Claudel and [Paul] Valéry" and expressing a "melancholy" regarding a lost enthusiasm and optimism (1970a, 89). Such self-deprecating comments are not rare for Schaeffer. Most strikingly, in an interview towards the end of his life, Schaeffer remarked that his musique concrète and its successors in fact never attained the level of music: "It took me forty years to conclude that nothing is possible outside DoReMi ... In other words, I wasted my life" (Hogdkinson 2001, 35). ${ }^{6}$ For Schaeffer, his musical research ultimately failed to escape the terms of Western art music. John Dack notes than such an ironic self-effacement is a consistent part of Schaeffer's rhetorical strategies (2017, xxix), and more substantially Martin Kaltenecker has argued that this self-effacement derives from Schaeffer's commitment to the extreme disciplinary methods of the mystic George Ivanovich Gurdjieff (2010). As such we should be wary of taking Schaeffer's more extreme self-deprecatory statements at face value. Here, however, I believe there is something more significant to extract from Schaeffer's negativity, not least because his comments anticipate later theoretical critique, and we can identify the theoretical issues he presents without necessarily following his rhetoric.

${ }^{5}$ The aporia that Chinn (2020) finds in Schaeffer's sound object, as well as in Walter Benjamin's aura, seems to me an aspect of the legacy of Kant's aesthetics, premised on instances where the determinate judgements of the transcendental subject do not seem to be able to account for what we perceive, demanding instead a non-conceptual reflective judgment. Indeed, as Robert Ryder suggests, Benjamin is on such terrain when he himself considers the relation between seashell, sound, and memory (2007; Helmreich 2012-13). The seashell as an, at least at first, undetermined object of inquiry that suggests a distinction between ways of viewing the world will be a thread running through my discussion here.

${ }^{6}$ This statement could be understood to refer either to musique concrète never leaving its foundational stage, or to a more fundamental failure regarding any attempt to overcome a universally valid truth of music: that the language of music is the language of the scale. There is a sense of Schaeffer vacillating between these positions, and it seems to me there are aspects of both in his self-deprecating remarks. 
Among those who have argued that Schaeffer's work failed to produce the decisive move beyond Western art music it attempted are Douglas Kahn, who positions Schaeffer among those twentieth-century composers who "liberate" sound only to bring an increasingly wider span of it under the conceptual rubric of "music" (1990, 68), Makis Solomos, who speaks of the "domestication" of noise through the figure of the sound object (2011), and Brian Kane, who situates Schaeffer within an unbroken "lineage of musical phantasmagoria" $(2014,10)$, arguing that the sound object "re-inscribes the ideality that was previously attached to the note" $(2014,34)$. Moreover, Kane's critique of Schaeffer rests on the analysis of a myth: not the myth of the seashell, but one associated with the akousmatikoi, students of the ancient Greek philosopher Pythagoras who purportedly, for reasons variously described as theological or pedagogical, listened to his teachings from behind a veil. For Kane, by situating the origin of acousmatics (concerning situations where sounds are heard without their cause being seen) and of reduced listening (a form of listening where the issue of a sound's cause is "bracketed" out of consideration) in a mythic understanding of the akousmatikoi and a supposed rediscovery of their originary experience, Schaeffer fails to account for the historical and technological specificity of his musical research $(2014,40)-41 ; 2019,68)$.

What I propose here, however, is that revisiting not the myth of the akousmatikoi but rather the myth of the seashell allows us to reconsider this critical discourse on Schaeffer. Specifically, where Kane finds in the myth of the Pythagorean veil and its relation to the grounding of reduced listening the closure of an ahistorical idealism, I will argue that the myth of the seashell points towards a form of myth that does not foreclose its object, that remains experimental and speculative. This argument will centre around Schaeffer's adoption of the phenomenology of Edmund Husserl, which is central to Kane's critique, with Schaeffer remarking in his Treatise that he "had often done phenomenology without knowing it" (1966, 262). ' I will examine Schaeffer's reflections in In Search of a Concrete Music, almost a decade after "Notes sur l'expression radiophonique" and more than a decade before the Treatise, on Paul Valéry's "Man and the Seashell”, arguing that the tentative thoughts Schaeffer expresses here reveal the impetus of his project towards refiguring the relation between subject and object, which lays out a persisting motivation in his thought and practice and nuances his later turn to Husserlian phenomenology.

\section{Sound and the seashell}

In the later, essayistic texts from In Search of a Concrete Music, the journals documenting Schaeffer's fledgling steps in developing musique concrète from 1948 to 1952, Schaeffer expands on his developing critique of "abstract music", targeting in particular the intellectualist application of serialist techniques in the elektronische Musik of the German

'While I have referred to, and owe much to, Christine North and John Dack's recent translation of the Treatise (Schaeffer 2017), all translations are my own. It should be noted that the edition of the Treatise cited is a 1977 update, with an additional "Penultimate Chapter" by Schaeffer inserted from page 663 onwards. 
avant-garde. ${ }^{8}$ He does this while formulating his notion of the sound object. For Schaeffer, abstract music operates on a relation between two subjects, composer and listener, and the zone between the two, the score or performance as something objective, "independent of the subjects who have composed or who will hear" $(2012,132)$, remains undertheorised. By not attending to this zone, music theory, argues Schaeffer, presents only "the rules of a completely fabricated art" $(2012,133)$, its musical procedures consisting in the application of "arbitrary preconceived schemas to concrete matter" $(2012,127)$. The general implication here is that an intersubjective relation between composer and listener is assumed, but rendered incoherent by a failure to consider the "gap" between the two, "a no-man's-land where nobody ventures” $(2012,132)$ but where the musical object itself lies, and to which Schaeffer directs his investigation.

At this point, Schaeffer's alternative remains ambiguous, the tentative and improvisatory character of these writings being evident. ${ }^{9}$ In order to clarify his thought, he turns back to his founding myth of the seashell, quoting Paul Valéry's "Man and the Seashell":

Looking at this seashell, in which I seem to see evidence of "construction" and, as it were, the work of a hand not operating by "chance", I am perplexed. I wonder: Who made this. ... My first stir of thought has been to think of making ... But soon my question undergoes a transformation. It takes a short step forward along the path of my naiveté, and I begin to inquire by what sign we recognize that a given object is or is not made by a man? (Valéry 1977, 117-18, translation modified; quoted in Schaeffer 2012, 147)

By examining Valéry's discussion of this encounter with the seashell, a remarkable object that is not easily grasped by our immediate understanding, Schaeffer revisits the themes of "Notes sur l'expression radiophonique" as well as La Coquille à planètes: themes of an undermining of passive, everyday forms of perception, of evoking something reducible neither to subjective experience nor to objective fact, of a profound resonance across the circuit of mind, body, shell, and world. Drawing from Valéry the discovery of a dynamic between an in some sense mysterious object and the possibility of its making, Schaeffer can begin to develop the implications for the subjectivity of listening, the objectivity of sound, and the relation between the two.

Many aspects of Schaeffer's reading appear quite obscure, so it is useful to first turn to Valéry himself. Valéry's text, recalling Kant's reflections on the beautiful, concerns the reaction of the mind to its encounter with natural forms, less so the "common disorder of perceptible things" than to "privileged objects": “a crystal, a flower, a seashell" (1977, 112). For Valéry these kinds of objects compel their perceiver to think, doing so on account of a fundamental tension between the perceiver's understanding of them as formed, structured objects that we could conceive of making, and the mystery behind how they came to be:

\footnotetext{
${ }^{8}$ For Schaeffer's fully developed account of his historical musical context, see the "Preliminary" chapter to the Treatise (1966, 15-38).

${ }^{9}$ Kane aptly describes Schaeffer's journals as documenting an "improvisational ontology" (2014, $15)$.
} 
"we do not understand their gradual formation, and that is what intrigues us" $(1977,113) .^{10}$ Such encounters "lead [man] to reflect on his own powers or tendencies" $(1977,109)$, and a particular satisfaction of thought results from achieving a grasp on the object's constitution, from "remak[ing] it in thought" (1977, 118; see Schaeffer 2012, 164). Here thought is understood as an active and dynamic procedure. For Valéry,

the greatest and most precious discoveries are quite unexpected. They demolish, more often than confirm, the products of our preferences: they consist in facts that are not yet humanized, that no imagination could have foreseen $(1977,126)$

From this perspective, Schaeffer considers how the seashell could stand as a metaphor for the sound object, an analogy which is, he says, "perfectly adequate" (2012, 147). He contrasts seashells and marbles: where marbles could represent the units, the notes, of music, with their simplicity allowing for easy organisation-"in piles, in staggered rows, in nice rhythmical series" (2012, 148)-the seashell, on the contrary, is not so easily manipulable. A year later, in "Vers une musique expérimentale", Schaeffer remarks that "experimental music" is to be concerned with "those sonorities which, being too complex and unheard of, escape the system of notation" (1970b, 108-09), "1 and in a more general sense Schaeffer takes the experience of hearing a sound object to be comparable to what Valéry describes when seeing a seashell: of being struck by, and not fully comprehending of, the form it presents. This urges a concern with the objectivity of the object, against any notion of the sound object as a merely "human phenomenon" (Schaeffer 2012, 133) to be manipulated at the composer's whims or mapped onto the listener's existing frameworks of understanding. As Schaeffer puts it:

the miracle of concrete music, which I am trying to get across to my interlocutor, is that in the course of experimentation, things begin to speak by themselves, as if they were bringing a message from a world unknown to us and outside us. (2012, 91-2)

For Schaeffer what the empiricist basis of musique concrète leads to, as a practice of listening, is that we encounter things that, on first hearing, we cannot fully account for:

the object forces us to listen to it, not by reference, but just as it is, in all the reality of its substance. As it doesn't say much, and certainly not what we would like it to say, once we have heard it, it makes us fall silent. In this silence we perceive new disturbances. (2012, 165)

${ }^{10}$ There is a desire here to bridge what Gilles Deleuze calls the "wrenching duality" of Kantian aesthetics, a duality between the experience of determinate objects of the understanding and the kind of undetermined objects we experience through art (1990a, 260). Such a desire is also behind ontological reflections in the phenomenology of art, as in the late work of Maurice Merleau-Ponty (2007).

${ }^{11}$ At this point in Schaeffer's writings the specific compositional method of musique concrète is largely supplanted by a syncretic research program concerning musique expérimentale. See Palombini (1993a) for an illuminating interpretation and contextualisation of this essay. 
But Schaeffer's concern is not only, as it is for John Cage, for example, with "letting sounds be themselves" (Cage 1961, 10). On the contrary, he finds a tension between, on one hand, the autonomy of sound objects that seem to elude our attempts to categorise them, and, on the other, "the importance of considering music in its subjective reality" $(2012,165)$.

As Schaeffer sees it, there have traditionally between two poles in the study of music and sound. The first is a relativistic conventionalism that reduces everything to language, placing itself on the side of the subject. The second is a scientism that places itself on the side of the object $(2012,158) .{ }^{12}$ Schaeffer's concern is to avoid these two poles and to find an adequate account for the relation between subject and object, one that is "intrinsic" rather than conventional $(2012,161)$. The project here, again, echoes Valéry, who asks:

do we not, ourselves, fluctuate between "the world of bodies" and that of the "mind"; and all our philosophy, is it not an eternal quest for the formula that will efface the difference between them and reconcile two different orders[?] $(1977,132)$

Following Valéry, for Schaeffer the question of language does not arise immediately on the encounter with the object, and, says Schaeffer, "we would do well to stop here for the time being" $(2012,126)$, with the risk being a conversion to the conventions of language. Shortly after this he suggests that the complexity of the sound object may demand not a prose language but a poetics $(2012,149)$. With this perspective in mind, the closing pages of $I n$ Search of a Concrete Music come as something of a surprise. Here Schaeffer, with the engineer, philosopher, and information theorist Abraham Moles as his co-author, begins his "Outline of a Concrete Music Theory" with "Twenty-five initial words for a vocabulary", a glossary of simply defined features and procedures of any concrete music $(2012,191)$. Moreover, this vocabulary is followed by an acoustical account of the characteristics of the sound object $(2012,194)$. Does this not reproduce the two poles of linguistic conventionalism and scientism that Schaeffer had before sought to evade? There is, perhaps, a tactical and tentative aspect to this, a juxtaposition of two types of taxonomy such that the tension between them reveals something of the space between the two. But it seems, nevertheless, a closure of possibilities, a slowing of the "improvisational ontology" (Kane $2014,15)$ of Schaeffer's inquiry, suggestive of the analytic of "typo-morphology" that marks the Treatise.

A useful starting point for interpreting this apparent deviation in Schaeffer's method is a consideration of the two mindsets with regards to the object that Schaeffer extracts from Valéry. To the uninitiated observer the object is a mystery, striking them as unexpected, unforeseeable by the imagination. Moreover, it remains this way $(2012,147)$. To the informed mind, on the contrary, the object is seen as something holding a certain form, where, despite its complexity, a certain understanding of its existence, of how it could be

\footnotetext{
${ }^{12}$ Schaeffer puts this distinction in vivid terms: "The first will say that everything is language; there is no question of a direct relationship between subject and object. The same old relativist arguments: the use of an object by man is nothing but a convention. The others, turning their backs on the former, allowing that one informs the other, will plug the human body into a galvanometer and will start to treat man like a frog” $(2012,158)$.
} 
made, is discerned and can be pursued. Schaeffer's emphasis on this distinction is telling with regards to the broad scope of his argument. He is here aligned with what in Valéry leads Gaston Bachelard to describe the latter as "essentially Cartesian" (1969, 106), namely a geometric form of the clear and distinct understanding of the objects we perceive. It seems that the "wrenching duality" of Kantian aesthetics, between determinate objects of the understanding and undetermined aesthetic objects, is solved through Descartes. For Bachelard the ambiguity in Valéry's thought, between the "original vortex" of life that is responsible for formation and beyond human understanding $(1969,106)$ and the Cartesian belief that, in Valéry's words, "all genuine knowledge reduces itself to what one sees and what one has power over” $(1977,126)$, ultimately settles on the latter position. The concern with formation, Bachelard argues, serves only to precede a "museum of forms": it is oriented towards a systematic understanding of the mind.

Schaeffer too is explicit in his debt to a Cartesian lineage of French thought. His Treatise is even bookended by quotes from Descartes, beginning, as does Valéry, with an affirmation of Cartesian methodological doubt $(1966,15)$, and ending by quoting from Descartes's Discourse on Method on the value of pursuing our own inquiries (1966, 703). But here I wish to stop short of integrating Schaeffer into the history of French Cartesianism. I want to dwell further on the ambivalence of this moment, when Schaeffer turned to Valéry and back to the myth of the seashell, and consider how this moment, and the problem discovered through it, persists in Schaeffer's thought. To bring out what I believe is a persisting problem in Schaeffer's project, and a fruitful problem at that, I will turn to what Brian Kane considers to be the ultimate grounding of the Treatise, to the phenomenology of Edmund Husserl $(2014,17)$.

\section{Phenomenology and the grounding of the sound object}

After a period of intense activity from 1948 to 1953 Schaeffer published little for over a decade, working in Africa for some years before returning to France and devoting himself to the Treatise, finally published in 1966. It is not easy to find a consistent theoretical framework for the Treatise, not least because of its compilation, despite the sole author attribution to Schaeffer, through extensive group research at the Groupe de recherches musicales (Teruggi 2017, xvi). Like much scholarship in France at the time the Treatise drew from structural linguistics, including bringing to musical research a tendency towards formal systematicity that was challenged in the widespread departure from structuralism that took place soon after (see Dosse 1997). But Schaeffer still, as he had when discussing Valéry, sought to avoid transposing a linguistic model onto music $(1966,129)$, and there is also widespread engagement with psychology, psycho-acoustics, information theory, and anthropology (Delalande 2009, 106; Valiquet 2017, 258). Yet Schaeffer's overriding focus on resisting the "scientific prejudice" of emphasising the object of inquiry $(1966,129)$ while nevertheless aiming to develop a scientific approach suitable to music $(1966,138)$ has led many commentators to emphasise Schaeffer's references to phenomenology, finding in the Treatise an attempt to produce a musical equivalent of phenomenology's "rigorous science" of subjective experience (Husserl 1965; Palombini 1993b, 57-58). 
On this topic of theoretical primacy, I remain agnostic. As Patrick Valiquet (2017) has argued, it seems more apt to take seriously the neologism Schaeffer places in the subtitle of the Treatise, that of the "interdiscipline", a notion perhaps not fully captured by the English language translators' rendering of "across disciplines", and that seems to suggest that Schaeffer's inquiry does not readily rest within any discipline or relation of disciplines. ${ }^{13}$ To overinvest in any discipline as being central thus risks a misunderstanding and misapplication of Schaeffer's project. With this in mind, what I aim to address in the pages ahead is a certain function that Husserlian phenomenology plays in Schaeffer's text, one that does not necessarily overdetermine the project as a whole, nor even the phenomenological aspects of his work as a whole, but which can nevertheless be found at work many different aspects and moments of Schaeffer's thought. This function, I will suggest, plays an important if not exhaustive role in both recent critical discourse on Schaeffer and in Schaeffer's disavowal of his own work.

Even among commentators who affirm the importance of phenomenology in Schaeffer's work, the specificity of this importance is not widely agreed upon. One option is to foreground the phenomenology of Maurice Merleau-Ponty, as Michel Chion does in his Guide des objets sonores (1983, 32). Indeed, something like Merleau-Ponty's embodied phenomenology can be heard in numerous passages in Schaeffer's early writings, particularly through his references to the primordial aspects of hearing: when he allusively speaks of how "instruments of flesh ... are capable of a symbolism of sensations stranger than the symbolism of language" (1970a, 91), or of a "whole body involved in the stimuli of [the] ear" $(2012,159)$. These passages suggest a fledgling materialism of sorts, a fleshly suturing of listening subject and sound object through a shared material ground. Yet Jacqueline Schaeffer, a psychoanalyst and the widow of Pierre, notes that when writing the Treatise Schaeffer had not read Merleau-Ponty, and it was at this time that Sophie Brunet introduced him to the phenomenology of Merleau-Ponty and Husserl (Schaeffer and Gayou 2009, 78). ${ }^{14}$ As such, while it is likely that Schaeffer received ideas from MerleauPonty's Phenomenology of Perception second hand, on account of its widespread influence on French intellectual life of the time, it cannot be seen as a sustained influence on Schaeffer's early thought.

By the time of the Treatise itself, however, I am inclined to agree with Brian Kane that Husserl's phenomenology does indeed take on a crucial role. And as Kane argues, Schaeffer's reliance on the mythic function of the Pythagorean veil plays an important part

\footnotetext{
${ }^{13}$ Schaeffer stresses that when discussing sound a continuity between disciplinary approaches cannot be assumed, and may not be possible or even desirable (1966, 160; Chion 2016, 196). Some recent discourse on transdisciplinarity, and notions such as "transdisciplinary objects" and "transdisciplinary problems" (Osborne 2015), seems apt to the way Schaeffer deals with sound, although applying this term to the Treatise would be anachronistic. While no easy translation thus offers itself, it is important to bear in mind that Schaeffer emphasises both disciplinary specificity and potentially transformative exchange.

${ }^{14}$ Schaeffer himself suggests that he encountered Merleau-Ponty's thought in the late 1950s (Pierret 1969, 123).
} 
in this $(2014,45)$. The reason for the importance of Husserl to the project of the Treatise is the centrality of a procedure that has a directly Husserlian provenance, and a procedure that has been of particular influence in sound studies, namely the acousmatic reduction. For Schaeffer, radio and other sound reproduction technologies place modern listeners in a situation analogous to that of the akousmatikoi, students of Pythagoras who listened to his teaching while he remained hidden behind a veil $(1966,91)$. This situation has brought to our attention the possibility of listening being directed towards sounds with no known cause. For Schaeffer what is offered here is the opportunity to isolate sounds from the audiovisual and referential complexes they occupy in everyday life, to "give oneself over entirely and exclusively to listening” $(1966,98)$.

While, as Kane has noted, readers of Schaeffer have often equated the acousmatic situation with reduced listening $(2014,37)$, the acousmatic situation itself does not imply any particular kind of listening. Indeed Schaeffer lays out four functions of listening that the acousmatic situation accommodates $(1966,103)$, such as the embodied listening of ouir, which could validate a Merleau-Pontyan reading, or the referential listening of comprendre. Michel Chion and Patrick Valiquet are among those who have rightly noted that, at the moment they appear in the Treatise, these functions are not the discrete modes of listening they have often been taken to be, but rather comprise an overlapping, mutually enriching relational field of listening (Chion 2019, 31; Valiquet 2017, 273). Yet when reduced listening appears, the only listening function that can be equated with it, that of entendre, takes on a certain primacy, and a hierarchy seems to emerge (Bonnet 2016, 74). If this form of listening seems more opaque than the others, this is because unlike those others it is a consciously applied procedure, a procedure that Schaeffer calls, following Husserl, a reduction.

For both Schaeffer and Husserl, the purpose of the reduction is to allow the perceiver to understand the formal characteristics of the experience we have of things in the world. As Husserl describes this reduction, it first involves a disengagement from, or "bracketing" of, what he terms the "natural attitude" or "natural standpoint": the belief that there is a "factually existing" world "out there", that things in the world exist independently of our consciousness $(1998, \S 30)$ ). Bracketing this standpoint allows us to turn our attention to how objects exist "for us", to the operations of our consciousness rather than any attempt to transcend it. To this is appended what Husserl terms "eidetic variation" (1998, §19; see Kane 2014, 30), which brings to the fore the very objectivity of the object of experience. Through a procedure of "imaginative free variation" we can discover what is essential to an object of experience. It is clear here that Schaeffer draws on Husserl to reformulate his attempts to do justice to both subjectivity and objectivity.

This procedure allows Schaeffer to clarify the more suggestive remarks of Valéry, detailing a "remak[ing] in thought" through which the essence of a perceived object can be grasped. For Schaeffer, it is only this procedure that can allow us to begin to understand the sound object: the reduction allows for the experience of perception itself to be grasped 
at the same time as the object which it presents to me. And then I realise that it is in my experience that the transcendence [of the object in relation to the changing flux of the different ways it is perceived] is constituted. $(1966,267)$

By separating hearing from the other sensory modalities, Schaeffer extends the Husserlian "anti-natural" step, disregarding the physical causation of given sounds so as to posit the sonic effect as an autonomous object. For Schaeffer the reduction thus allows for an approach that takes an intermediary position between the two extremes in the theorisation of sound, namely the natural attitude of an objective science of acoustics and the subjective projection of music theory onto sound matter. Through the examination of sounds in variation, Schaeffer begins to discern the characteristics of them as sound objects. As Kane describes this move, "[l]istening becomes a sphere of investigation containing its own immanent logic, structure, and objectivity” (2014, 24).

This clears some space for engaging with sound objects without either objective or subjective predeterminations, and the Treatise does much to carry this through. So why does Schaeffer ultimately bemoan the failure of his musical research? I believe that the debates around Husserl's ultimate solution to the gap between subject and object suggest some aspects of why Schaeffer loses faith in his attempt to formulate a new musical language. Husserl's solution to this problem is the notion of the noema: the object construed as neither an act of consciousness nor as a physical thing, but as an ideal object (see Smith 2007, 57). The role of the noema is to come into coincidence with the selfgivenness of the object at the same time as it comes into coincidence with a self-given consciousness, what in Schaeffer's terms we might put as how listener and sound as perceived can have a relation amounting to a single procedure of identifying a sound object.

How this coincidence can take place for Husserl has been a matter of great debate, with two leading strands of interpretation. ${ }^{15}$ Adopting Hubert Dreyfus's terminology, these can be named as concept theory and percept theory (2014, 47; Chukwu 2009). Put simply, concept theory argues that the meaning of the noema is semantic, that it has a sense-making function that gives it an essentially linguistic character (Dreyfus 2014, 65). This takes the noema away from the world and towards abstract, conceptual understanding, as the content of a positing consciousness rather than an actual object in the world. Percept theory, on the other hand, places the noema on the side of the perceptual object, but ultimately at the expense of the transcendental ego itself, its self-givenness no longer guaranteed thanks to the transformative impact perceptual objects could have on it (Gurwitsch 1966, 291, 341). On Dreyfus's account, with percept theory the perceptual object has to be accepted as given, that is to say, as an existing object, and therefore not subject to a complete transcendental reduction $(2014,72)$.

Here we again feel the pull between a linguistic conventionalism and a scientific realism that Schaeffer sought to avoid. For Dreyfus it is only the concept theory interpretation that remains faithful to Husserl's project, a reading that can be extended to

\footnotetext{
${ }^{15}$ My formulation of this debate owes much to Bell (1998).
} 
Schaeffer: their respective projects concern a subjective grounding of objective understanding, antithetical to the epistemologically ungrounded nominalism suggested by percept theory. But insofar as Husserl and Schaeffer are positing concept theories, they risk succumbing to the same problems as their respective points of departure in Kantian transcendental philosophy and Western art music, namely, of losing that which is sensuous in experience in favour of formal conceptual schemas. Yet by finding in Schaeffer's adoption of Husserl a decisive turn to idealism, Kane perhaps neglects how the purported idealism of Husserl's philosophy remains a topic of significant debate. ${ }^{16}$ Reinvestigating Husserlian phenomenology here could prove a fruitful path to reappraising Schaeffer.

In the case of Schaeffer what seems most pertinent to his abandonment and apparent disavowal of musical research is not his being pulled towards the pole of the concept, but rather his failure to resolve the contradictory pull between concept and percept. Here the impetus produced by the myth of the seashell, the impetus to give an adequate account of both subjectivity and objectivity, persists. It is true that in the theory of the sound object we find a process of experimentation, as documented in In Search of a Concrete Music, slowed and formalised through a taxonomical demarcation of the field of sound, and it is on this basis that Kane locates Schaeffer firmly within a lineage of musical phantasmagoria. This posits a concept theory approach, and the typo-morphology of the Treatise does seem to tend in this direction. But again, in another late interview, Schaeffer argues that music "has to find a compromise and an evasion at the same time" with regards to its two sources of sounds, namely noises and instruments (quoted in Kahn 1999, 110). The former are circumscribed by their association with the experience of the everyday, the latter by the weight of music theory, and neither attain an adequate level of objectivity. It seems that for Schaeffer the tensions between concept and percept, in the form of music and noise among other conceptual binaries, ultimately overwhelm his project and its attempts to reformulate the relation between subject and object.

Schaeffer's earlier writings provide many hints of means by which he could have attempted to navigate the difficult passage between concept and percept otherwise, but there are nevertheless profound reasons why Schaeffer would turn to Husserl. Schaeffer was clear even in his early research that the relation between abstract music and concrete music would not be an opposition but an exchange $(2012,28)$, and such an alternative as the fleshly ontology of Merleau-Ponty would perhaps have had too great an aversion to abstraction, too much distance from systematicity and scientificity, to provide a satisfyingly rigorous counterpoint to the formal complexity of abstract music. ${ }^{17}$ By turning to Husserl, Schaeffer strives to take on the formal complexity of abstract music on its own terms. Yet

\footnotetext{
${ }^{16}$ It is in marked contrast to Kane's reading of Husserl that Husserl maintained a complex relationship to realism, and with this a complex relationship to contemporary realist thought. See Zahavi (2017, 33, 170).

${ }^{17}$ There has, however, been important recent work that places Merleau-Ponty's thought in closer proximity to the abstractions associated with science and mathematics than has often been supposed of it. See Matherne (2018).
} 
the reading that associates Schaeffer with a concept theory interpretation of Husserlian phenomenology seems to occlude a fundamental problematic that animates Schaeffer's project, which leads him to denounce this project towards the end of his life. This is a problematic of accounting for both the subjective and objective features of the encounter with sound objects. How can we revisit this problematic and think it anew?

\section{Myth revisited: the problematic of sound}

To consider this, I return again to Valéry, and hope to maintain the phenomenological problem posed by Schaeffer's reflections on the seashell. Valéry's Cartesianism remains relevant here, as Valéry too sought a certain rigour, a form of scientificity to define his way of seeing and reasoning (Robinson-Valéry 1999, 70). But there may be a more subtle form of Cartesianism than the distinction that Schaeffer draws between the mindsets with regards to the object, of ignorance and understanding. Jacques Bouveresse reads Valéry's Cartesianism, following Valéry's own remarks on philosophy, as a paradoxical "antiphilosophical" Cartesianism, and Valéry's "system" as one in which the mind is only understandable in its transformations $(1995,379)$. Bouveresse's reading allows us to see that Schaeffer's engagement with Valéry could have produced a more unstable form of systematicity than that implied in the avowed desire to discover the universal properties of listening to which Schaeffer ultimately devoted his efforts (Chion 2019, 24-25; Valiquet 2017). This more unstable systematicity could, perhaps, have maintained the autonomy given to the voice of the object, the object as an object of encounter. These aspects of Schaeffer's "improvisational ontology" no doubt become obscured within the Husserlian model.

These suggestive claims can be clarified by looking back at Gaston Bachelard's account of Valéry, where Bachelard values Valéry's concern with the "original vortex" of life but wishes to stop short of the Cartesianism that he sees as diminishing that primal moment. Bachelard's articulation of this problem is particularly relevant to the tensions in Schaeffer's project, insofar as across his thought Bachelard develops a heterogeneous resonance between science and poetics. Drawing again from Valéry, Bachelard, speaking of poetry, argues that moments of ambiguity are moments that allow the ideas that poetry holds to unsettle the mind, to spark the transformative procedures of thought:

the temporal structure found in ambiguity can help us to intellectualise rhythms produced by sound, and so enable us to think that poetry which will not reveal all its charms when we confine ourselves to speaking or feeling it. We have come to realise that it is the idea that sings its song, that the complex interplay of ideas has its own tonality, a tonality that can call forth deep within us a faint, soft murmuring. $(2016,139)$

Such a notion of thought in action is present too in Bachelard's work on the scientific mind. Here Bachelard takes to be of central interest the process through which scientific objects are formalised, from indiscernible sensuous matter to precise objects that can be subjected to rigorous study. This corresponds to the projects of Husserl and Schaeffer, but Bachelard thoroughly rejects the notion that a fully-formed transcendental subject can account for the formation of knowledge. He instead proposes a "non-Cartesian” epistemology $(1984,138)$ 
through which there can be no clear distinction between the subject of experience and the theoretical object of knowledge. The subjective lens-historically and technically situated, as evident in Bachelard's interest in scientific instruments and "phenomeno-technology" $(1984,13)^{18}$-must enter into a process of desubjectification with regards to its object, while in turn constructing that very object. In this Bachelard can be seen to take, like Schaeffer, a certain phenomenological impetus to rethink the status of subjectivity and objectivity.

Bachelard will come to conceptualise this non-Cartesian epistemology in terms of what he calls the problematic (1966, 9-10). By this term Bachelard means to suggest that engaging with problems is a creative and productive act, on both the side of the subject and of the object, with the procedures of science taking place less between subject and object than within a single problematic field. In the words of the philosopher of science Hans-Jörg Rheinberger, "[subject] and object do not face one another directly in the experiment, but are engaged in mutual instruction" $(2010,24)$. The scientific mind "exists only as a history of involvement in and entanglement with the phenomena that it investigates", ${ }^{19}$ and, in Bachelard's terms, this means that we must speak not so much of the well-defined objects of science than of processes of objectification $(1984,167)$. What is crucial here is that the object is always understood in its nascent state, and it is in this nascent state, echoing Valéry and Schaeffer on the seashell, that the object has the capacity for expressivity. For Bachelard the formalisation of the scientific object is always in process, and formalisation is necessarily incomplete, impure, subject to encounters and mutations. Through this impurity the either/or of scientific realism and subjective interpretivism that is a consistent target for Schaeffer is collapsed.

To read Schaeffer in this light is at this point speculative, but another thinker dealing with the problematic allows us to develop this further. For Gilles Deleuze, the problematic Idea is an object of encounter "which can only be sensed" (1994, 139), something new and unexpected rather than an object of comprehensive recognition, where thought remains active in relation to its object. Here we can recognise something like how Valéry and Schaeffer pose the initial encounter with the seashell, before they strive to turn it into an object of understanding. And this is not the only place where Deleuze can help us, as in three separate essays he distinguishes between two notions of myth that suggest a path that, at least according to critical perspectives, Schaeffer did not take.

As Kane views Schaeffer's deployment of the myth of the Pythagorean veil, myth serves as an explanatory principle, giving sense to all chains of events, but at the exclusion of contingency and historicity. This is a kind of myth that Deleuze outlines in "Lucretius

\footnotetext{
${ }^{18}$ The contrast between Bachelard's phenomeno-technology and Schaeffer's own rejection of any technological specificity to his research project could be a fruitful line of further inquiry. See Teruggi (2007) and Gayou (2007).

${ }^{19}$ Such a notion could help us better understand what Patrick Valiquet describes as the "historically specific 'listener function', a bundle of auditory relationships and knowledge about audition that circumscribes aural subjecthood in terms proper to French intellectual life in the 1960s" to be found in Schaeffer's Treatise $(2017,257)$.
} 
and the Simulacrum”. In this essay Deleuze, affirming a Nietzschean naturalism, poses an opposition between Nature and myth. Myth, on a trajectory encompassing the origins of language, conventions of law and justice, and the development of war among much more, is the expression of a "false infinite" and the force of the negative, a principle of totality and closure $(1990 \mathrm{~b}, 279)$. This is opposed to the pluralism and affirmation associated with Nature, with naturalism being the means by which the speculative object and the practical object of philosophy coincide (1990b, 278): where they exist problematically.

However, another sense of myth is presented in the text "Desert Islands". Here Deleuze describes myth as a basis for a "beginning anew", as the ingenious interpretation of that which is no longer understood $(2004,12)$. Later, when writing of T. E. Lawrence, Deleuze discusses Lawrence's projection of his own mythic image, "an image that is always stitched together, patched up, continually growing along the way, to the point where it becomes fabulous" $(1997,118)$. The myth that posits a totality brings with it the risk of closure, but the myth that maintains a degree of obscurity, of inexplicability, persists as a source of invention.

What would it mean for our understanding of Schaeffer's thought to maintain a focus on the mythic function of the seashell as an impetus to rethink the relation of subject and object? Can the latter sense of myth Deleuze describes be applied to it? I would like to suggest that it can. We can see this in Rey Chow's recent challenge to Kane's claim that the use of myth in Schaeffer's elaboration of the sound object leads to the closure of Schaeffer's project (2019, 128n22). For Chow, Schaeffer's engagement with antiquity is better understood within the context of the aesthetic experiments of modernism, where antiquity and procedures of reduction are deployed in order to "make customary phenomena leap forward in a new frame" $(2019,118)$, an act of "reflexivity and renewal" with regards to the everyday. Despite Schaeffer's own reluctance to accept the technological specificity of the acousmatic situation, Chow argues that supplanting the Pythagorean veil with technological sound reproduction lends to the acousmatic situation a distinctly different valence than the closure of Husserlian reduction, and that the use of myth here produces an exemplary instance of the indistinction of boundaries between ideal and concrete objects $(2019,128-29 n 22)$.

Chow thus shows that this is not a matter only of the myth of the seashell versus the myth of the veil, and that the mythic function is more mutable than such an opposition implies. I would like to suggest, drawing together, Bachelard, Deleuze, and Chow, that with reduction and myth we can speak of what we could call esoteric and exoteric effects, or effects of closure and experimental effects. When engaged with the exoteric effects of the myth of the veil we could consider François Bonnet's discussion of acousmatic listening and hallucination, noting how "the imagination [runs] away with itself when confronted with the experience of listening" $(2016,173)$. This suggests sound objects not as something to be discovered or uncovered, but to be fabulated, a fabulous sound object that builds a world 
around itself. ${ }^{20}$ The esoteric myth of the veil may suggest a subject that folds in on itself, but the exoteric myth of the seashell proposes a reflexive reformulation of subject and object.

Such a polyvocal notion of myth could lead our engagement with Schaeffer away from the universalist certainties that are a key goal of the Treatise, albeit a goal never achieved, to Schaeffer's ultimate despondence. Consider the remarks of the pioneering environmental writer Rachel Carson:

To understand the shore, it is not enough to catalogue its life. Understanding comes only when, standing on the beach, we can sense the long rhythms of earth and sea that sculptured its land forms and produced the rock and the sand of which it is composed; when we can sense with the eye and ear of the mind the surge of life beating always at its shores-blindly, inexorably pressing for a foothold. To understand the life of the shore, it is not enough to pick up an empty shell and say "This is a murex", or "That is an angel wing”. (Carson 1955, vii)

These sentiments seem comparable to the unexpected novelty that Valéry and Schaeffer find in their encounter with the seashell, but the move to then pin down these objects in the understanding is not so quick. The feminist and ecological epistemologist Lorraine Code draws on these passages from Carson to suggest the complexity and contingency of classification, remarking that "classifications are multiply contestable", in part because they are dependent on "the habitats, patterns, or processes in which seemingly distinct organisms and entities interact" (2006, 50; Doucet 2018). In the context of Schaeffer's call for the "primacy of the ear", this raises a question, as posed by John Levack Drever (2019): whose ear? The typo-morphology of the Treatise is a solution to the persisting phenomenological problematic that the myth of the seashell poses, but if presented as a partial, provisional, contingent solution, it can offer us more than a foreclosed and failed project. Carson and Schaeffer both show that the seashell poses a problem of experience with some clarity, but its solution remains open.

What I propose, then, is that dwelling on Schaeffer's early reflections on the sound object and the seashell gives us the opportunity to think about sound in a richly "problematic" way, to open up its contingencies, and our contingencies. It brings about a phenomenological problematic that demands an adequate account of both subjectivity and objectivity. In this context, Schaeffer's recourse to myth and reduction need not be the insurmountable impasse suggested by Schaeffer's critics, and even by Schaeffer himself. ${ }^{21}$ The pull between subjective and objective need not be seen as a flaw or an aporia. It can rather be a lens for understanding the heterogeneous and incomplete research project that Schaeffer documented in the Treatise and elsewhere. The "myth" of the seashell may only

\footnotetext{
${ }^{20}$ Simon O'Sullivan's reflections on "myth-science" are illuminating on the notions of fabulation and the fabulous (2016).

${ }^{21}$ There is more to pursue regarding the Gurdjieffian discipline that plays a role in Schaeffer's selfdeprecation. In Schaeffer's case at least this discipline seems to present itself as an external, and destructive, form of self-critique. The question arises of what position Schaeffer would have come to if he were able to produce a self-critique on a more immanent or reflexive basis.
} 
be that it demands a perpetual reevaluation of subject and object, and any account of the esoteric effects of myth and reduction must be coupled with an account of the exoteric effects, the reductive with the experimental and speculative. With this Schaeffer's sense of objects speaking by themselves, and the impulse to think provoked by our tenuous, contingent, and partial understanding of this speech, can be pursued again.

\section{References}

Alloa, E., F. Chouraqui and R. Kaushik. 2019. "Merleau-Ponty and Contemporary Philosophy: An Introduction.” In Merleau-Ponty and Contemporary Philosophy, edited by E. Alloa, F. Chouraqui, and R. Kaushik, 1-14. Albany: State University of New York Press.

Bachelard, G. 1966. Le rationalisme appliqué [3rd edition]. Paris: Presses Universitaires de France.

Bachelard, G. 1969. The Poetics of Space. Translated by M. Jolas. Boston: Beacon Press.

Bachelard, G. 1984. The New Scientific Spirit. Translated by A. Goldhammer. Boston: Beacon Press.

Bachelard, G. 2016. The Dialectic of Duration. Translated by M. McAllester Jones. London: Rowman \& Littlefield.

Bell, J. A. 1998. The Problem of Difference: Phenomenology and Poststructuralism. Toronto: University of Toronto Press.

Bonnet, F. J. 2016. The Order of Sounds: A Sonorous Archipelago. Translated by R. Mackay. Falmouth: Urbanomic.

Bouveresse, J. 1995. "Philosophy from an Antiphilosopher: Paul Valéry.” Critical Inquiry 21 (2): 354-381. doi:10.1086/448756.

Cage, J. 1961. "Experimental Music.” In Silence: Lectures and Writings, 7-12. Middletown, CT: Wesleyan University Press.

Carson, R. 1955. The Edge of the Sea. Boston: Houghton Mifflin.

Chinn, L. 2020. "The aporia of the veil: the influence of Walter Benjamin's aura in contemporary sound studies." Sound Studies 6 (1): 2-13. doi:10.1080/20551940.2019.1709015.

Chion, M. 1983. Guide des objets sonores : Pierre Schaeffer et la recherche musicale. Paris: Institut national de l'audiovisuel \& Éditions Buchet/Chastel.

Chion, M. 2016. Sound: An Acoulogical Treatise. Translated by J. A. Steintrager. Durham: Duke University Press. 
Chion, M. 2019. "Reflections on the Sound Object and Reduced Listening." In Sound Objects, edited by J. A. Steintrager and R. Chow, 23-32. Durham: Duke University Press.

Chow, R. 2019. "Listening after 'Acousmaticity': Notes on a Transdisciplinary Problematic.” In Sound Objects, edited by J. A. Steintrager and R. Chow, 113129. Durham: Duke University Press.

Chukwu, P. 2009. Competing Interpretations of Husserl's Noema: Gurwitsch Versus Smith and McIntyre. New York: Peter Lang.

Code, L. 2006. Ecological Thinking: The Politics of Epistemic Location. Oxford: Oxford University Press.

Dack, J. 1994. "Pierre Schaeffer and the Significance of Radiophonic Art." Contemporary Music Review 10 (2): 3-11. doi:10.1080/07494469400640251.

Dack, J. 2017. "Pierre Schaeffer's Treatise on Musical Objects and Music Theory.” In P. Schaeffer, Treatise on Musical Objects: An Essay across Disciplines, translated by C. North and J. Dack, xxix-xxxiv. Oakland: University of California Press.

Dack, J. 2019. "Pierre Schaeffer and the (Recorded) Sound Source.” In Sound Objects, edited by J. A. Steintrager and R. Chow, 33-52. Durham: Duke University Press.

Delalande, F. 2009. "Schaeffer and Research.” Polychrome Portraits no. 14: Pierre Schaeffer, edited by É. Gayou, 103-107. Paris: Institut national de l'audiovisuel.

Deleuze, G. 1990a. The Logic of Sense. Translated by M. Lester with C. Stivale. New York: Columbia University Press.

Deleuze, G. 1990b. "Lucretius and the Simulacrum." In The Logic of Sense, translated by M. Lester with C. Stivale, 266-279. New York: Columbia University Press.

Deleuze, G. 1994. Difference and Repetition. Translated by P. Patton. New York: Columbia University Press.

Deleuze, G. 1997. "The Shame and the Glory: T. E. Lawrence.” In Essays Critical and Clinical, translated by D. W. Smith and M. A. Greco, 115-125. Minneapolis: University of Minnesota Press.

Deleuze, G. 2004. "Desert Islands.” In Desert Islands and Other Texts 1953-1974, edited by D. Lapoujade and translated by M. Taormina, 9-14. Los Angeles: Semiotext(e).

Dosse, F. 1997. History of Structuralism, Volume 2: The Sign Sets, 1967-Present. Translated by D. Glassman. Minneapolis: University of Minnesota Press.

Doucet, A. 2018. "Shorelines, seashells, and seeds: Feminist Epistemologies, Ecological Thinking, and Relational Ontologies." In The Palgrave Handbook of Relational Sociology, edited by F. Dépelteau, 375-391. London: Macmillan. 
Dreyfus, H. 2014. “The Perceptual Noema: Gurwitsch's Crucial Contribution.” In Skillful Coping: Essays on Everyday Perception and Action, edited by M. A. Wrathall, 47-75. Oxford: Oxford University Press.

Drever, J. L. 2019. “'Primacy of the Ear' - But Whose Ear?: The case for auraldiversity in sonic arts practice and discourse.” Organised Sound 24 (1): 85-95. doi:10.1017/S1355771819000086.

Gayou, É. 2007. “The GRM: landmarks on a historic route.” Organised Sound 12 (3): 203-211. doi:10.1017/S1355771807001938.

Gurwitsch, A. 1966. Studies in Phenomenology and Psychology. Evanston: Northwestern University Press.

Helmreich, S. 2012-13. "Seashell Sound." Cabinet 48. http://www.cabinetmagazine.org/issues/48/helmreich.php.

Hodgkinson, T. 2001. "An Interview with Pierre Schaeffer.” In The Book of Music and Nature: An Anthology of Sounds, Words, Thoughts, edited by D. Rothenberg and M. Ulvaeus, 34-44. Middletown, CT: Wesleyan University Press.

Husserl, E. 1965. "Philosophy as a Rigorous Science." In Phenomenology and the Crisis of Philosophy, translated by Q. Lauer, 122-147. New York: Harper \& Row.

Husserl, E. 1998. Ideas pertaining to a pure phenomenology and to a phenomenological philosophy: first book. Translated by F. Kersten. Dordrecht: Kluwer Academic Publishers.

Kahn, D. 1990. “Track Organology.” October 55: 67-78. doi:10.2307/778938.

Kahn, D. 1999. Noise, Water, Meat: A History of Sound in the Arts. Cambridge, MA: The MIT Press.

Kaltenecker, M. 2010. "Résonances théologiques de l'écoute chez Pierre Schaeffer." Droits de Cité 4. http://droitdecites.org/2010/10/15/kaltenecker.

Kane, B. 2014. Sound Unseen: Acousmatic Sound in Theory and Practice. Oxford: Oxford University Press.

Kane, B. 2015. "Sound studies without auditory culture: a critique of the ontological turn.” Sound Studies 1(1): 2-21. doi:10.1080/20551940.2015.1079063.

Kane, B. 2019. "The Fluctuating Sound Object.” In Sound Objects, edited by J. A. Steintrager and R. Chow, 57-30. Durham: Duke University Press.

Kant, I. 2000. Critique of the Power of Judgement. Translated by P. Guyer and E. Matthews. Cambridge: Cambridge University Press.

Kim-Cohen, S. 2009. In the Blink of an Ear: Toward a Non-Cochlear Sound Art. New York: Continuum. 
Matherne, S. 2018. "Merleau-Ponty on abstract thought in mathematics and natural science.” European Journal of Philosophy 26: 780-797. doi:10.1111/ejop.12315.

Merleau-Ponty, M. 2007. "Eye and Mind.” In The Merleau-Ponty Reader, translated by G. Johnson and M. Smith and edited by T. Toadvine and L. Lawlor, 351-378. Evanston: Northwestern University Press.

Nadrigy, P. 2013. "La musique expérimentale selon Pierre Schaeffer, l'expérience phénoménologique à l'épreuve du laboratoire / Experimental Music According to Pierre Schaeffer: Phenomenology Laboratory Conditions.” Tacet 2: 22-57.

O’Sullivan, S. 2016. "Myth-Science and the Fictioning of Reality.” Paragrana 25 (2): 8093. doi:10.1515/para-2016-0030.

Osborne, P. "Problematizing Transdisciplinarity, Transdisciplinary Problematics." Theory, Culture \& Society 32(5-6): 3-35. doi:10.1177/0263276415592245.

Palombini, C. 1993a. "Pierre Schaeffer, 1953: Towards an Experimental Music.” Music and Letters 74 (4): 542-557. doi:10.1093/ml/74.4.542.

Palombini, C. 1993b. Pierre Schaeffer's Typo-Morphology of Sonic Objects. PhD dissertation: Durham University. http://etheses.dur.ac.uk/1191/.

Pierret, M. 1969. Entretiens avec Pierre Schaeffer. Paris: P. Belfond.

Rheinberger, H-J. 2010. On Historicizing Epistemology: An Essay. Translated D. Fernbach. Stanford: Stanford University Press.

Robinson-Valéry, J. 1999. “The fascination of science.” In Reading Paul Valéry: Universe in mind, edited by P. Gifford and B. Stimpson, 70-84. Cambridge: Cambridge University Press.

Ryder, R. 2007. "Walter Benjamin's shell-shock: Sounding the acoustical unconscious.” New Review of Film and Television Studies 5 (2): 135-155. doi:10.1080/17400300701432811

Schaeffer, J. and É. Gayou, 2009. "Living with a Tireless Thinker.” In Polychrome Portraits no. 14: Pierre Schaeffer, edited by É. Gayou, 77=81. Paris: Institut national de l'audiovisuel.

Schaeffer, P. 1966. Traité des objets musicaux : essai interdisciplines. Paris: Éditions du Seuil.

Schaeffer, P. 1970a. "Notes sur l'expression radiophonique.” In Machines à communiquer 1. Genèse des simulacres, 89-118. Paris: Éditions du Seuil.

Schaeffer, P. 1970b. "Vers une musique expérimentale." In Machines à communiquer 1. Genèse des simulacres, 156-163. Paris: Éditions du Seuil.

Schaeffer, P. 2012. In Search of a Concrete Music. Translated by C. North and J. Dack. Berkeley: University of California Press. 
Schaeffer, P. 2017. Treatise on Musical Objects: An Essay across Disciplines. Translated by C. North and J. Dack. Oakland: University of California Press.

Smith, D. W. 2007. Husserl. London: Routledge.

Solomos, M. 2011. "Bruits « entonnés " et sons « convenables " : Russolo et Schaeffer ou la domestication des bruits.” Filigrane. Musique, esthétique, sciences, société. Numéros de la revue, Musique et bruit.

Steintrager, J. A. and R. Chow. 2019. “Sound Objects: An Introduction.” In Sound Objects, edited by J. A. Steintrager and R. Chow, 1-19. Durham: Duke University Press.

Teruggi, D. 2007. "Technology and musique concrète: the technical developments of the Groupe de Recherches Musicales and their implication in musical composition.” Organised Sound 12 (3): 213-331. doi:10.1017/S1355771807001914.

Teruggi, D. 2017. "The Treatise on Musical Objects and the GRM.” In P. Schaeffer, Treatise on Musical Objects: An Essay across Disciplines, translated by C. North and J. Dack, xv-xix. Oakland: University of California Press.

Valéry, P. 1977. "Man and the Sea Shell.” In Paul Valéry: An Anthology, translated by J. Mathews and edited J. R. Lawler, 108-135. London: Routledge \& Kegan Paul.

Valiquet, P. 2017. "Hearing the Music of Others: Pierre Schaeffer's Humanist Interdiscipline.” Music \& Letters 98 (2): 255-280. doi:10.1093/ml/gcx052.

Zahavi, D. 2017. Husserl's Legacy: Phenomenology, Metaphysics, and Transcendental Philosophy. Oxford: Oxford University Press. 